\title{
INVESTIGATION OF SOME FACTORS AFFECTING THE HOLE DIGGER PERFORMANCE IN THE SANDY SOIL
}

\author{
M. M. Atallah ${ }^{(1)}$, S. K. Khalil, ${ }^{(1)}$ M. T. Ebaid ${ }^{(2)}$
}

\section{ABSTRACT.}

The aim of this research is to study some factors affecting the hole digger performance in the sandy soil. The experiments were conducted in ElKasasin Research Station in El-Sharkia Governorate. Auger diameters $(250 \mathrm{~mm})$ of the developed hole-digger were tested at different augerspeeds (75, 100 and 150 rpm), auger pitches (10, 15 and $20 \mathrm{~cm})$, holedepths ( 20, 30 and $40 \mathrm{~cm}$ ), hole-spacing $(5 \mathrm{~m})$ and soil type (sandy) with moisture contents of 15, 22 and $32 \%$.

The obtained results can be summarized as follow:

The maximum hole productivity rate for sandy soil was 335 hole/h obtained with auger speed of $150 \mathrm{rpm}$, hole depth $20 \mathrm{~cm}$, auger pitch 20 $\mathrm{cm}$ at moisture content $32 \%$. The penetration resistance of sandy soil at $15 \%$ moisture content increased by 30 and $40.6 \%$ as compared with of sandy soil at moisture content $22 \%$ and $32 \%$, respectively. The maximum fuel consumption was $0.59 \mathrm{~L} / \mathrm{h}$ was obtained with auger speed of $150 \mathrm{rpm}$, hole depth $40 \mathrm{~cm}$, and auger pitch $10 \mathrm{~cm}$. The maximum power requirements $1.91 \mathrm{~kW}$ was obtained with auger speed of $150 \mathrm{rpm}$, hole depth $40 \mathrm{~cm}$, auger pitch $10 \mathrm{~cm}$ and moisture content $15 \%$. The minimum operation cost was 0.04 L.E/hole at auger pitch $15 \mathrm{~cm}$ and hole depth $20 \mathrm{~cm}$. Whereas, the maximum operation cost was 0.14 L.E./hole at auger pitch $10 \mathrm{~cm}$ and hole depth $40 \mathrm{~cm}$. The operational cost using a hole digger attached to a power tiller decreased by $371 \%$ compared with manual digging.

\section{INTRODUCTION.}

The greatest two environmental problems in the world are the desertification due to cutting the forest trees for wood and sand movement from desert to cultivated lands. These problems could be solved by cultivation and tree planting.

(1) Res., Ag. Eng. Res. Institute and (2) Senior Res. 
Governments take care of tree-planting projects for windbreaks, minimizing of air pollution.

Various agricultural machines were manufactured to save time and effort, and to protect the environment. The hole digger is one of the most important machines used in these objectives. The devolved machine must be not expensive, simple in construction and work in all environmental conditions.

Kapnehko et al. (1976) recommended a hole digger of $30-100 \mathrm{~cm}$ diameter at penetration speed $1-25 \mathrm{~cm} / \mathrm{s}$ to establish holes for apples. The consumed time was found to be 8,9 and $12-20 \mathrm{~s}$ for diameters of 30,60 and $80-100 \mathrm{~cm}$ respectively. The hole digger establishes $100-$ 150 hole / $\mathrm{h}$ for a depth of $60 \mathrm{~cm}$ at speed of $180 \mathrm{rpm}$.

Purtskhvanidze and Keller (1990) tested a hole digger for making onslopes attachment to a hand-operated tractor $2 \mathrm{~kW}$. They found the tractor saved about $20-30 \%$ in power consumption.

Kathirvel, et al. (1990) developed the auger digger as attachment to power tiller of $8-10 \mathrm{hp}$ to dig holes for planting seedlings. The unit is capable of digging 35 - 40 hole / h. The machine digs hole of $22.5 \mathrm{~cm}$ diameter up to a depth of $45 \mathrm{~cm}$.

El Shal (1993) tested the digger operated with tractor after using a chisel plow with depth of $20 \mathrm{~cm}$. It was found that the productivity of hole digger increased with increasing moisture content of soil and decreasing of the soil depth and resistance.

The maximum productivity of hole digger of 138 hole/h was obtained by using hole depth of $50 \mathrm{~cm}$, moisture content $18 \%$, hole diameter of 40 $\mathrm{cm}$ and sandy soil. Meanwhile, the minimum productivity of hole digger of 66 hole / h was obtained with clay soil by using hole depth of $100 \mathrm{~cm}$, moisture content $11 \%$ and hole diameter of $60 \mathrm{~cm}$. The digging efficiency of hole digger increased with increasing the hole depth, hole diameter, resistance and moisture content of soil. The minimum digging efficiency of $64 \%$ was obtained by using hole diameter of $40 \mathrm{~cm}$, hole depth $50 \mathrm{~cm}$ and moisture content $11 \%$ in sandy soil. 
Minaei and Arizdeh (2000) designed and developed auger drill for attachment to two wheels tractors for tree-seedlings planting. The machine digs hole of $180 \mathrm{~mm}$ diameter up to a depth of $400 \mathrm{~mm}$. Field experiments in showed that the moisture content and soil resistance are two important factors in the bit penetration rate. Drilling rate increased with increasing soil moisture content and decreasing soil penetration resistance. The average drilling rate in sandy clay soil with $25 \%$ moisture content was $1.4 \mathrm{~m} / \mathrm{min}$. The unit is capable of digging 100 holes in one hour.

Chaaban et al. (2007) and Khalil (2008) designed and tested a hole digger attached to power tiller. They found that the minimum total digging time with cleaning was $56 \mathrm{~s}$ and obtained with auger speed of $200 \mathrm{rpm}$, hole diameter $15 \mathrm{~cm}$, hole depth $20 \mathrm{~cm}$, and sandy soil. The minimum penetration resistance was $18.1 \mathrm{~N} / \mathrm{cm}^{2}$ for sandy soil at soil depth of $20 \mathrm{~cm}$. The power requirements increased in loamy soil than sandy loamy and sandy soil by 14.8 and $28.4 \%$ respectively at different parameters. The minimum fuel consumption of $0.37 \mathrm{~L} / \mathrm{h}$ was obtained with auger speed of $75 \mathrm{rpm}$, auger diameter $15 \mathrm{~cm}$, hole depth $20 \mathrm{~cm}$, hole spacing $1 \mathrm{~m}$ and sandy soil. The minimum power requirements of $1.18 \mathrm{~kW}$ was obtained with auger speed of $75 \mathrm{rpm}$, hole diameter $15 \mathrm{~cm}$, hole depth $20 \mathrm{~cm}$, hole spacing $1 \mathrm{~m}$ and sandy soil. The minimum average range of operation costs with and without cleaning were 0.12 and $0.016 \mathrm{~L} . \mathrm{E} / \mathrm{hole}$ respectively for sandy soil at auger diameter $15 \mathrm{~cm}$, hole depth $20 \mathrm{~cm}$ and hole spacing $1 \mathrm{~m}$.

Kathirvel et al. (1990) indicated that the cost of digging holes and the time consumed by power tiller hole digger was minimum as compared to the manual digging by $6 \%$ for making 100 holes. Also, they found the cost of hole digging decreased by $179 \%$ as compared to the digger operated with tractor.

Yehia et a!̣. (2009) found that the maximum hole productivity of 324 hole/h was obtained with auger speed of $150 \mathrm{rpm}$, hole diameter $15 \mathrm{~cm}$, hole depth $20 \mathrm{~cm}$, auger pitch $20 \mathrm{~cm}$ at moisture content $26 \%$. The maximum fuel consumption was $0.69 \mathrm{~L} / \mathrm{h}$ was obtained with auger speed 
of $150 \mathrm{rpm}$, hole diameter $25 \mathrm{~cm}$, hole depth $40 \mathrm{~cm}$, and auger pitch 10 $\mathrm{cm}$. The maximum power requirements was $2.72 \mathrm{~kW}$ was obtained with auger speed of $150 \mathrm{rpm}$, hole diameter $25 \mathrm{~cm}$, hole depth $40 \mathrm{~cm}$, auger pitch $10 \mathrm{~cm}$ and moisture content $18 \%$. The operation costs by using a hole digger attached to a power tiller decreased by about $500-950 \%$ compared with manual digging.

The objective of the present work is to study the affecting factors on performance of a developed hole digger (which designed by Chaaban et al., 2007 and Khalil, 2008) such as auger pitch, speed and moisture content of sandy soil in order to improve the performance of this implement.

\section{MATERIALS AND METHODS.}

\subsection{Experimental site:}

The experiments were carried out during the years of 2011 and 2012 in El-Kasasin Research Station, at moisture contents of 15, 22 and $32 \%$. The mechanical analysis of the experimental soil was classified as sandy soil as shown in Table 1.

Table 1: Mechanical analysis of the experimental soil .

\begin{tabular}{|c|c|c|c|c|}
\hline Soil Depth & Sand, \%. & Silt, $\%$. & Clay, \%. & Soil Texture class \\
\hline $0-40 \mathrm{~cm}$ & 93 & 6 & 1 & Sandy \\
\hline
\end{tabular}

(1) The developed hole-digger: The developed hole digger (which designed by Chaaban et al., 2007 and Khalil, 2008) is shown in fig. 1(a,b). The developed hole-digger consists of the following parts :

(a) Frame: The frame was made of square-section steel tubing with dimensions of $80 \times 80 \mathrm{~mm}$, with thickness of $3 \mathrm{~mm}$. The total length of frame is $375 \mathrm{~mm}$ and width is $355 \mathrm{~mm}$. The height of frame from soil level is $525 \mathrm{~mm}$. 

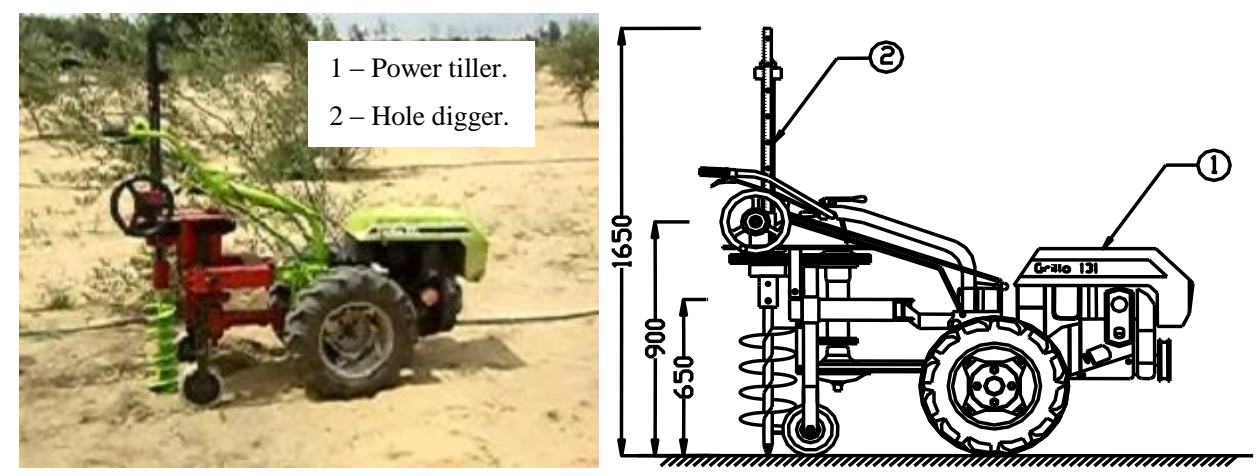

(a) 1740

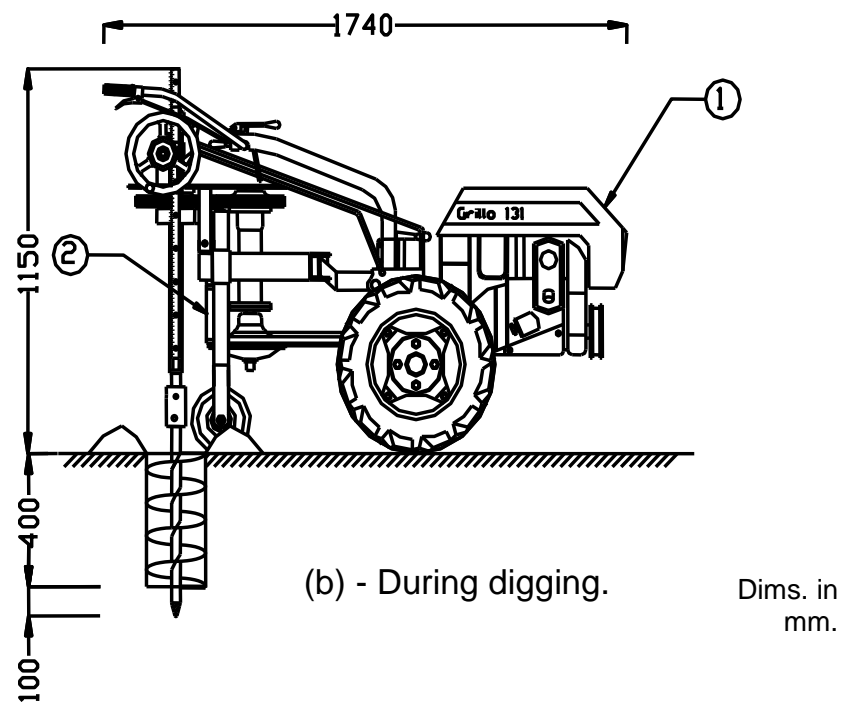

Fig. 1: View of the developed hole digger attached to a power tiller

(b) Two stands with ground wheels: Two stands and two ground wheels carry the frame and all parts of the hole digger. Each stand was made of square-pipe steel of $50 \times 50 \mathrm{~mm}$, with thickness of $3 \mathrm{~mm}$. The total length of stand is $550 \mathrm{~mm}$. The distance between two stands is 400 $\mathrm{mm}$. Two plastic ground-wheels were attached with the bottom of stands by two pins. The diameter of each ground wheel is $200 \mathrm{~mm}$ and the width is $45 \mathrm{~mm}$. 
(c) Hexagonal steel-shaft: The augers were fitted with the bottom of hexagonal steel-shaft by steel ring and pin. The power is transmitted to the hexagonal shaft by two gears. The hexagonal shaft was fitted with second gear with hexagonal ring. The hexagonal shaft is $42 \mathrm{~mm}$ diameter and $800 \mathrm{~mm}$ total length.

(d) Depth-gauge (adjusting) mechanism: The mechanism consists of three parts: (a) Gear with 21 teeth, $66 \mathrm{~mm}$ diameter and $33 \mathrm{~mm}$ thickness, (b) The rack with length of $870 \mathrm{~mm}$, width of $32 \mathrm{~mm}$ and number of teeth 83 and (c) Manual wheel with $250 \mathrm{~mm}$ diameter rotated by welded handle with length of $125 \mathrm{~mm}$.

(e) Auger (Fig. 2): Auger with diameter $250 \mathrm{~mm}$ was constructed and tested. The total length of auger was $625 \mathrm{~mm}$. The auger pitch " $\mathrm{p}_{\mathrm{t}}$ " affects the penetration and cutting into soil. Too small or too large pitch will make it more difficult to penetrate soil. In fact, the penetration angle " $\alpha$ " can be calculated and is shown in table $\mathbf{2}$ as fallows:

$$
\alpha=\tan ^{-1}\left(\frac{p_{t}}{2 d}\right)
$$

Where " $\alpha$ " increased from the outer edge of auger helix to the inside of its flute. Moreover the optimum penetration angle depends on soil type and compaction.

Table 2: The relation between auger diameter, auger pitch and.

penetration angle of auger

\begin{tabular}{||c||c|c|c||}
\hline \multicolumn{1}{|c||}{ Auger diameter, $\mathrm{cm}}$. & \multicolumn{3}{|c|}{25} \\
\hline \hline Auger pitch, $\mathrm{cm}$. & 10 & 15 & 20 \\
\hline Penetration angle. & $11^{\circ}$ & $17^{\circ}$ & $22^{\circ}$ \\
\hline
\end{tabular}

The steel type of the auger knife was named "Bohler K100 or DIN 1.2080 X210Cr12". The chemical composition of steel knife (Bohler company - 2006) is shown in table 3 .

Table 3: The chemical composition of steel knife of auger.

\begin{tabular}{|c|c|c|c|c|c|}
\hline \multicolumn{7}{|c|}{ The elements, \%. } \\
\hline $\mathrm{C}$ & $\mathrm{Si}$ & $\mathrm{Mn}$ & $\mathrm{Cr}$ & $\mathrm{Ni}$ & $\mathrm{W}$ \\
\hline 1.98 & 0.19 & 0.32 & 11.84 & 0.18 & 0.05 \\
\hline
\end{tabular}

C: carbon Si: Silicon Mn: Manganese Cr: Coram Ni: Nickel W: Tungsten 
The hardness of the knife steel is up to $63-65$ HRC HRC (Hardness Rockwell Scale) at temperature of 940 to $970 \mathrm{C}^{\circ}$.

(2) Power tiller: Power transmissions from power tiller auger of hole digger was shown in fig. 3. The specifications of the power tiller were as follow:

Model: Grillo 131, Italian made, Engine power: $10 \mathrm{~kW}$ (13.6 hp), speed: 5 forward speeds $(1.2-4.2 \mathrm{~km} / \mathrm{h})$ and 2 reverse speeds $(0.8-1.7 \mathrm{~km} / \mathrm{h})$ and power take-off (PTO) speed: $1028 \mathrm{rpm}$.
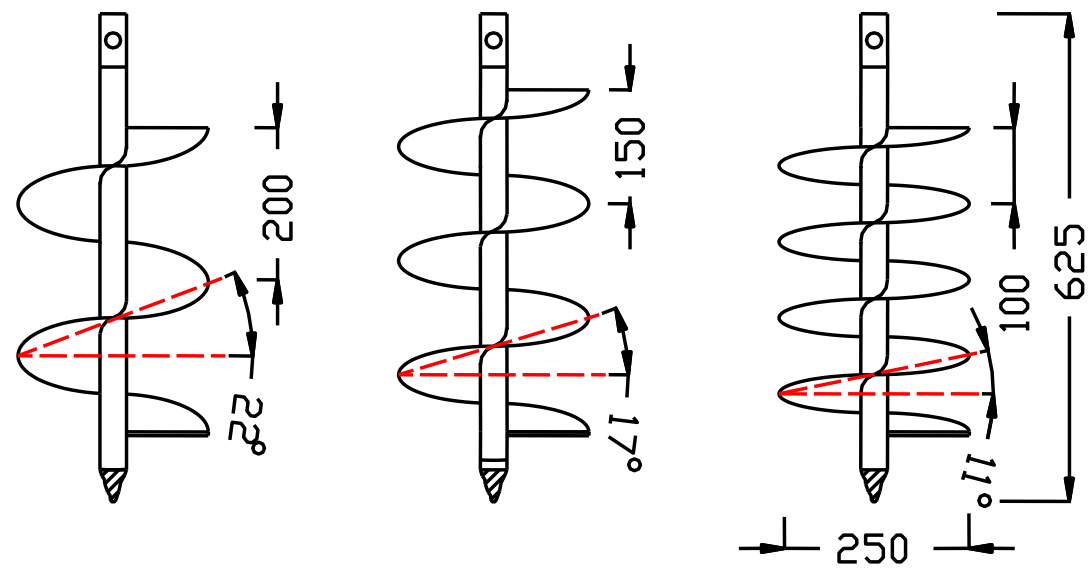

Dim. in $\mathrm{mm}$.

Fig. 2: The Auger of different pitches 100, 150 and $200 \mathrm{~mm}$.

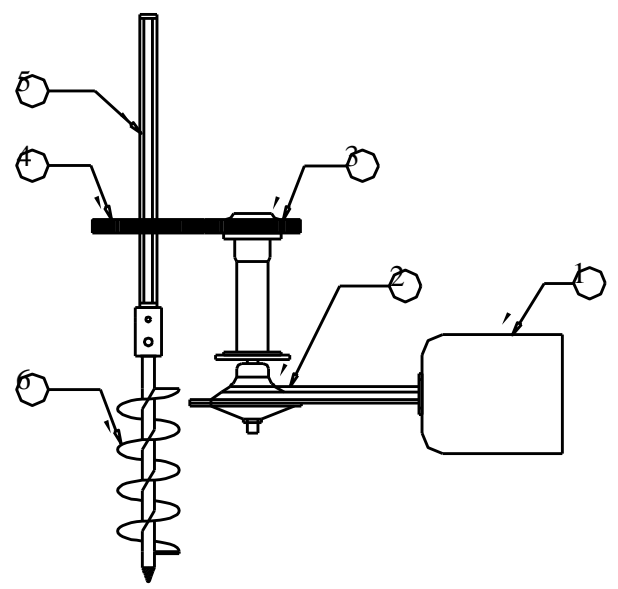

1 - The PTO speed of power tiller is $1028 \mathrm{rpm}$.

2 - Gear box consists of two bevel gears which has tranmuittion ratio of $4: 1$.

3 - The first gear of 62 teeth.

4 - The second gear of 72 teeth.

5 - The hexagonal shaft.

6 - The auger (max. speed $200 \mathrm{rpm}$ ).

Fig. 3: Power transmissions from power tiller to auger of hole digger 


\subsection{Instrumentations:}

(a) Pentrometer resistance measurements: Soil penetration can be measured by a cone penetrometer. A cone penetrometer was specified by A S A E S 3I3-1 as cited by Agricultural Engineers as 30 circular stainless steel cone with driving shaft. The cone index has been defined as the force per unit depth of penetration according to the following equation:

$$
\mathrm{R}=\mathrm{F} / \mathrm{A} \quad \ldots \ldots \ldots \ldots \ldots \ldots \ldots \ldots \ldots+\mathrm{cm}^{2}
$$

Where: $\mathrm{R}=$ Specific soil penetration, $\mathrm{F}=$ Required force, and $\mathrm{A}=$ Projected area of penetrometer. The push type penetrometer was used to determine penetrometer resistance of the soil profile before digging operations.

(b) Speedometer: A speedometer was used to measure the auger speed with the three ranges available: $1^{\text {st }}$ range $5-50 \mathrm{~m} / \mathrm{min}$. $(50-500 \mathrm{rpm})$ direct reading. $2^{\text {nd }}$ range $50-500 \mathrm{~m} / \mathrm{min}$. $(500-5000 \mathrm{rpm})$ scale value $\mathrm{rpm} \times 10.3^{\text {rd }}$ range $500-5000 \mathrm{~m} / \mathrm{min}$. $(5000-50000 \mathrm{rpm})$ scale value $\mathrm{rpm} \times 100$.

\subsection{Measurements:}

(1) Fuel consumption and power requirement: Fuel consumption was determined by measuring the required fuel to refill the fuel tank after the treatment period. Consumed energy per feddan was calculated through measuring fuel consumption for each of treatment operating speed. The power tiller was instrumented to measure run time and fuel consumption. The consumed energy was calculated by using the following formula:

$$
\mathbf{P}=3.23 F_{c} \text { cited by (Hunt, 1983). }
$$

Where: P=Power requirements $(\mathrm{kW}), \quad \boldsymbol{F}_{c}=$ The fuel consumption $(\mathrm{L} / \mathrm{h}$.).

(2) Digging efficiency: The percentage volume of the soil resulted from the digging was estimated by measuring the height $\left(\mathrm{H}_{1}\right)$ and the width $(\mathrm{L})$ of heaped soil round the hole (Fig. 4). Where: $\mathrm{L}=\mathrm{R}_{1}-\mathrm{R}_{0} \mathrm{~cm}$. All measurements were carried out at three angular speeds of 75, 100 and $150 \mathrm{rpm}$, auger-diameter of $25 \mathrm{~cm}$ and three hole-depths of 20,30 and 40 $\mathrm{cm}$. To achieve the highest digging efficiency and shape uniformity of the hole, $\mathrm{R}_{1}$ had to be $\leq 3-3.5 \mathrm{R}_{0}$ (Scripnic, 1968). Moreover, volume of 
the soil resulted from digging must be equal to hole volume multiplied by the swelling factor of soil.

$$
H_{l}=\frac{K_{a} H_{0}\left(R_{0}\right)^{2}}{R_{g}\left(R_{1}-R_{0}\right)}
$$

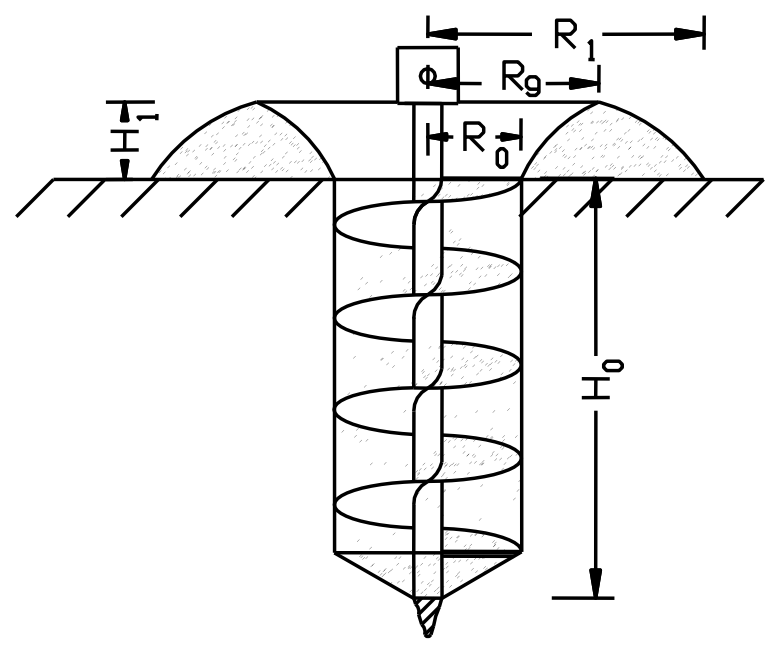

Fig. 4: Hole dimensions.

Where: $\mathrm{R}_{0}$ : Radius of the hole, $\mathrm{cm}, \mathrm{R}_{1}$ : Radius from the end of the accumulated soil., $\mathrm{cm}, \mathrm{R}_{\mathrm{g}}$ : Radius from the center to the middle of the accumulated soil, $\mathrm{cm}, \mathrm{H}_{1}$ : The height of the soil resulting from digging, $\mathrm{cm}, \mathrm{H}_{0}$ : Hole depth, cm, and $\mathrm{K}_{\mathrm{a}}$ : swelling factor. Swelling factor $\left(\mathrm{K}_{\mathrm{a}}\right)$ was calculated for sand soil (1.58).

The digging efficiency was calculated by using the following formula:

$$
\eta_{d}=\frac{V_{\text {res. }}}{V_{\text {total }}} \times 100
$$

Where: $\eta_{d}=$ Efficiency of the digging, $V_{\text {res. }}=$ Volume of the soil resulted from the digging (soil outside the hole), $V_{\text {total }}=$ Volume of the total soil inside and outside the hole.

(3) Cost: The operation costs of the designed hole digger attached to a power tiller calculated according to equation of Awady, 1978 in the following form: $\mathrm{C}=\frac{\mathrm{P}}{\mathrm{h}}\left(\frac{1}{\mathrm{a}}+\frac{\mathrm{i}}{2}+\mathrm{t}+\mathrm{r}\right)+(1.2$ w.s.f $)+\frac{\mathrm{m}}{144}$ 
Where: $\mathrm{C}=$ Hourly cost, $\mathrm{P}=$ Price of the machine and power tiller, $\mathrm{h}=$ Yearly working hours, $\mathrm{a}=$ Life expectancy of the machine in years, $\mathrm{i}=$ Interest rate/year, $\mathrm{t}=$ Taxes rate, $\mathrm{r}=$ Repairs and maintenance ratio, $\mathrm{w}=$ Power of the machine $\mathrm{kW}, \mathrm{s}=$ Specific fuel consumption $\mathrm{L} / \mathrm{kW} . \mathrm{h}, \mathrm{f}=$ Fuel price L.E./L , $\mathrm{m}=$ Monthly wage, $1.2=$ Factor accounting for ratio of rated power and lubrications, $144=$ The monthly average working hours.

Table 4: The constants used in Awady equation:

\begin{tabular}{|c|c|c|c|c|c|c|c|c|c|}
\hline P, L.E. & $\begin{array}{c}\text { h, } \\
\text { h/year }\end{array}$ & a, year & i, $\%$ & t, $\%$ & r, \% & $\begin{array}{c}\text { w, } \\
\text { kW }\end{array}$ & $\begin{array}{c}\text { s, } \\
\text { L/kW.h }\end{array}$ & $\begin{array}{c}\text { f, } \\
\text { L.E/L }\end{array}$ & $\begin{array}{c}\text { m, } \\
\text { L.E/month }\end{array}$ \\
\hline 21000 & 1000 & 10 & 7 & 5 & 6 & 10 & 0.36 & 0.6 & 1000 \\
\hline
\end{tabular}

$* \mathrm{P}=$ price of a hole digger + power tiller $=3000+18000$

** Measured specific fuel consumption.

Cost of digging one holes $=\frac{\text { Hourly } \cos t, L E}{\text { Holes production per hour }} . . . .$. LE/hole

\section{RESULTS AND DISCUSSION.}

\subsection{Penetration resistance.}

Fig. 5 shows the penetration resistance for sandy soil at different moisture content and different soil depths. The maximum penetration resistance was $41.5 \mathrm{~N} / \mathrm{cm}^{2}$ at $15 \%$ moisture content and soil depth 40 $\mathrm{cm}$. Whereas, the minimum penetration resistance was $16.2 \mathrm{~N} / \mathrm{cm}^{2}$ at 32 $\%$ moisture content and soil depth $20 \mathrm{~cm}$. The increasing of penetration resistance by increasing the soil depth and decreased of moisture content.

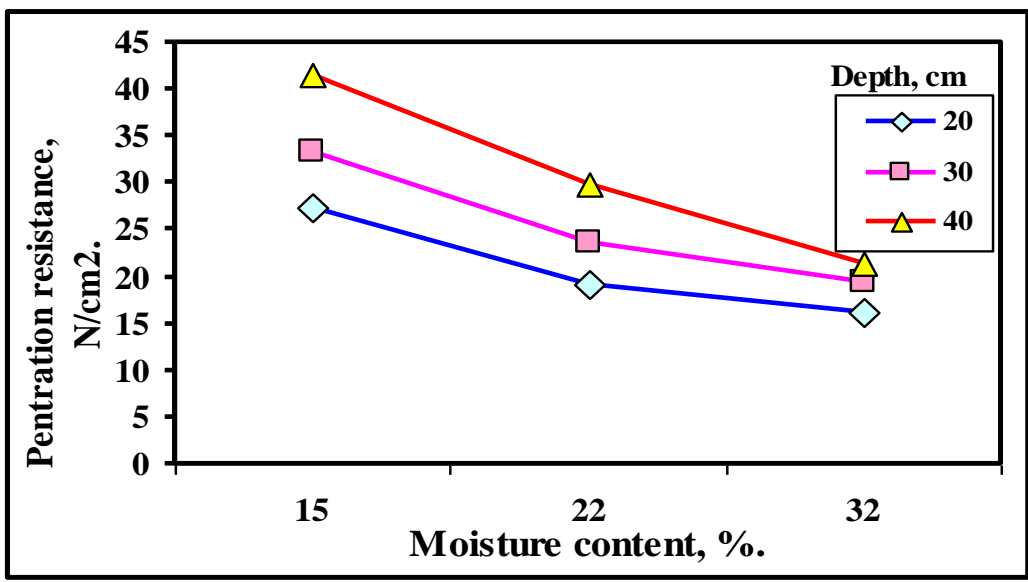

Fig. 5: Penetration resistance for sandy soil at different moisture-contents and soil-depths. 


\subsection{Effect of auger speed, auger pitch (penetration angle), moisture content and hole depth on hole-digging production rate for hole diameter $25 \mathrm{~cm}$ and sandy soil.}

Fig. 6 shows the effect of auger speed, auger pitch, moisture content and hole depth on hole-digging production rate for sandy soil. The maximum hole productivity of 335 hole/h was obtained with auger speed of 150 rpm, hole depth $20 \mathrm{~cm}$, auger pitch $20 \mathrm{~cm}$ at moisture content $32 \%$. Whereas, the minimum hole productivity of 100 hole/h was obtained with auger speed of $75 \mathrm{rpm}$, hole depth $40 \mathrm{~cm}$ and auger pitch $10 \mathrm{~cm}$ at moisture content $15 \%$. The hole digging productivity increased with increasing auger speed, auger pitch and moisture content, decreased by increasing hole depth.

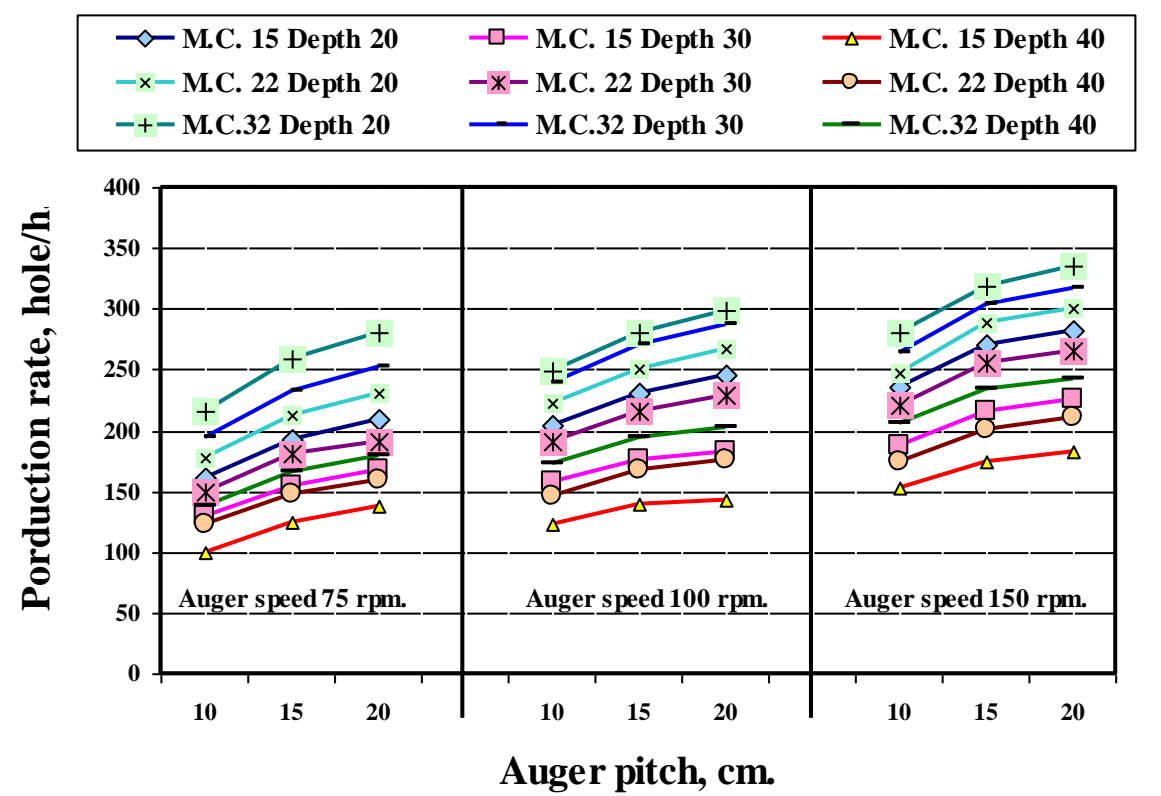

Fig. 6: Effect of auger speed, auger pitch, moisture content (\%) and hole depth on hole-digging production rate for sandy soil.

\subsection{The effect of different working parameters on digging efficiency $\%$.}

Fig. 7 shows the effect of auger speed, auger pitch, moisture content and hole depth on digging efficiency for sandy soil. The digging efficiency increased by increasing auger speed, hole depth and moisture content of soil. The maximum digging efficiency was $95 \%$ at auger speed $150 \mathrm{rpm}$, auger pitch $20 \mathrm{~cm}$, hole depth $40 \mathrm{~cm}$ and moisture content $32 \%$. 
Whereas, the minimum digging efficiency was $39 \%$ at auger speed 75 rpm, auger pitch $10 \mathrm{~cm}$, hole depth $20 \mathrm{~cm}$ and moisture content $15 \%$.

The increasing of digging efficiency is due to increasing the mass of digging soil. The increasing of digging efficiency by increasing soil moisture-content is due to decreasing soil stability.

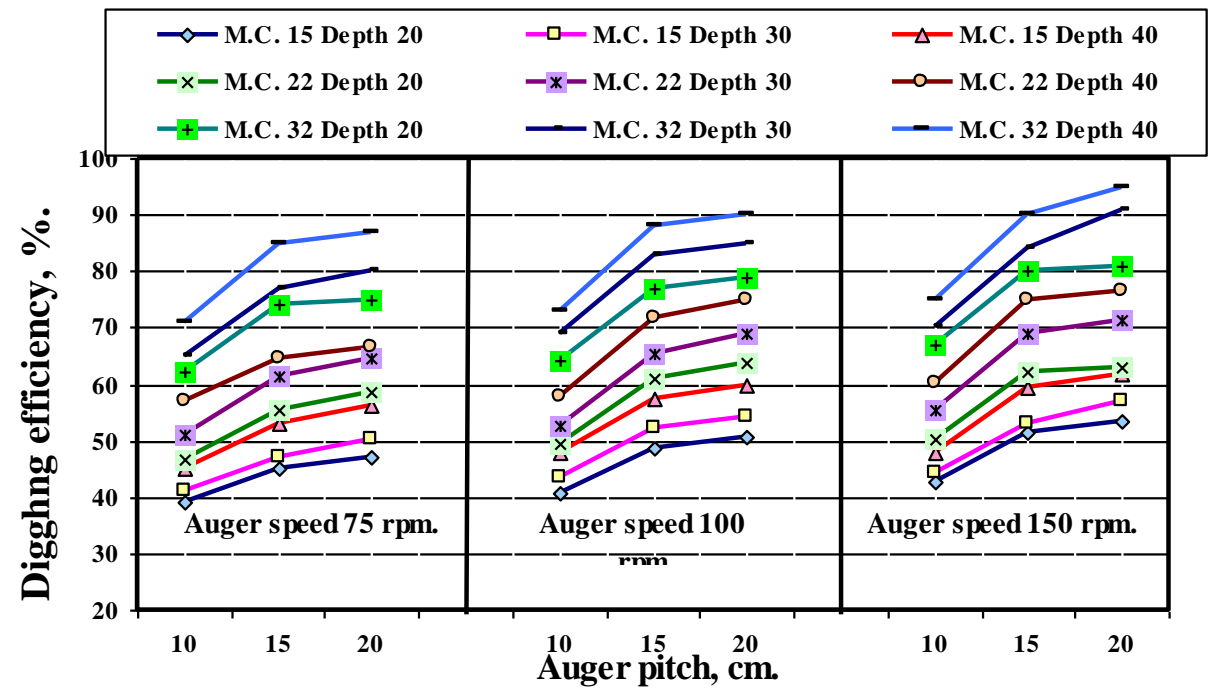

Fig. 7: Effect of auger speed, auger pitch, moisture content (\%) and hole depth on digging efficiency for sandy soil.

\subsection{The effect of different working parameters on fuel consumption.}

Fig. 8 shows the effect of auger speed, auger pitch, moisture content and hole depth on fuel consumption. The maximum fuel consumption was $0.59 \mathrm{~L} / \mathrm{h}$ was obtained with auger speed of $150 \mathrm{rpm}$, hole depth $40 \mathrm{~cm}$, auger pitch $10 \mathrm{~cm}$ and moisture content $15 \%$. Whereas, the minimum fuel consumption of $0.27 \mathrm{~L} / \mathrm{h}$ was obtained with auger speed of $75 \mathrm{rpm}$, hole depth $20 \mathrm{~cm}$, auger pitch $20 \mathrm{~cm}$ and moisture content $32 \%$. The fuel consumption of the developed hole-digger increased with increasing auger speed, hole depth and soil resistance. The increasing of fuel consumption by decreasing soil moisture content and auger pitch is due to increasing penetration soil-resistance.

\subsection{The effect of different working parameters on power requirements}

Fig. 9 shows the effect of auger speed, auger pitch, moisture content and hole depth on power requirements. The maximum power requirements was $1.91 \mathrm{~kW}$ was obtained with auger speed of $150 \mathrm{rpm}$, hole depth 40 
$\mathrm{cm}$, auger pitch $10 \mathrm{~cm}$ and moisture content $15 \%$. Meanwhile the minimum power requirements of $0.87 \mathrm{~kW}$ was obtained with auger speed of $75 \mathrm{rpm}$, hole, hole depth $20 \mathrm{~cm}$, auger pitch $20 \mathrm{~cm}$ and moisture content $32 \%$. The power requirements of the developed hole-digger increased with increasing auger speed, hole depth and soil resistance. The increasing of power requirement by decreasing soil moisture content and auger pitch is due to increasing penetration soil-resistance.

\begin{tabular}{|c|c|c|}
\hline$\neg$ M.C. 15 Depth 20 & $-\square-$ M.C. 15 Depth 30 & $\triangle-$ M.C. 15 Depth 40 \\
\hline -x-M.C. 22 Depth 20 & -*- M.C. 22 Depth 30 & - - M.C. 22 Depth 40 \\
\hline-+- M.C. 32 Depth 20 & $\neg$ M.C. 32 Depth 30 & $\square-$ M.C. 32 Depth 40 \\
\hline
\end{tabular}

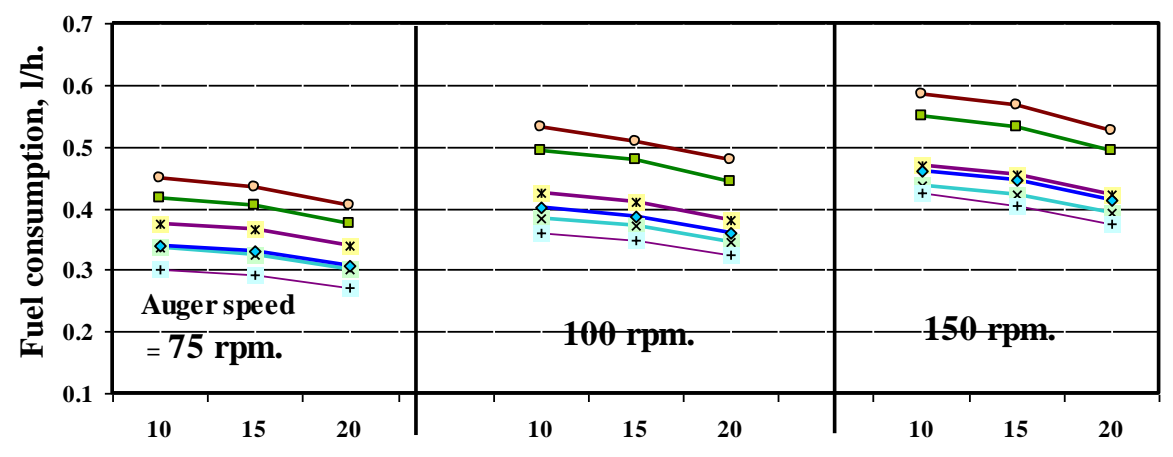

Auger pitch, cm.

Fig. 8: Effect of auger speed, auger pitch, moisture content (\%) and hole depth on fuel consumption of digging the sandy soil.

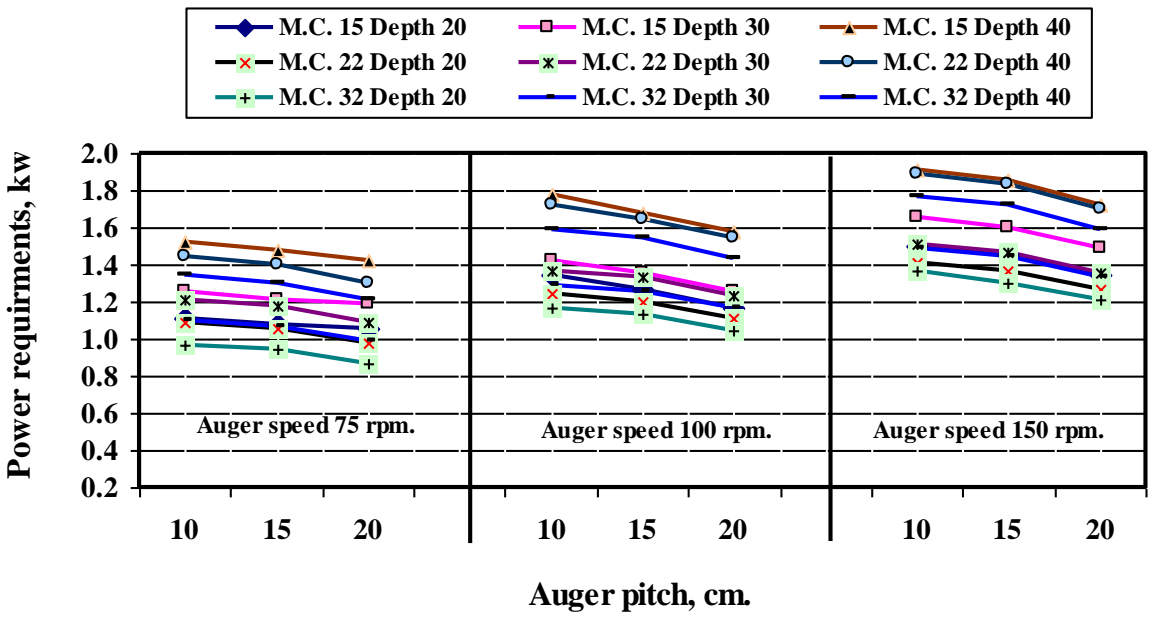

Fig. 9: Effect of auger speed, auger pitch, moisture content and hole depth on power requirements of digging the sandy soil. 


\subsection{Cost of using the modified hole digger.}

Table 5 shows the effect of auger pitch, hole depth, and soil moisturecontent on operation cost of hole digger speed of $150 \mathrm{rpm}$ in sandy soil. The minimum operation cost was $0.04 \mathrm{~L}$.E/hole at auger pitch $15 \mathrm{~cm}$, hole depth $20 \mathrm{~cm}$ and soil moisture-content $32 \%$. Whereas, the maximum operation cost was 0.14 L.E./hole at auger pitch $10 \mathrm{~cm}$, hole depth $40 \mathrm{~cm}$ and soil moisture-content $15 \%$. The operation cost increased by increasing hole depth and soil penetration resistance at different parameters. Table 6 shows the hole productivity and operation cost for one hole by using manual digging at auger pitch of $15 \mathrm{~cm}$, moisture content of $32 \%$ and different hole-depths and auger- pitch. diameters. The operation cost by using a hole digger attached to a power tiller decreased by about $371 \%$ compared with manual digging.

Table 5: Cost of using a developed hole-digger at auger speed of 150 rpm and different soil moisture-content, hole-depths and augerpitch.

\begin{tabular}{|c|c|c|c|c|}
\hline \multirow{3}{*}{$\begin{array}{c}\text { Moisture } \\
\text { content } \\
\text { of soil, \%. }\end{array}$} & \multirow{3}{*}{$\begin{array}{r}\text { Hole } \\
\text { depth, } \\
\text { cm. }\end{array}$} & \multicolumn{3}{|c|}{ Cost, L.E./hole. } \\
\hline & & \multicolumn{3}{|c|}{ Auger diameter, $25 \mathrm{~cm}$. } \\
\hline & & $\begin{array}{l}\text { Auger pitch, } \\
10 \mathrm{~cm} .\end{array}$ & $\begin{array}{c}\text { Auger pitch, } \\
15 \mathrm{~cm} .\end{array}$ & $\begin{array}{c}\text { Auger pitch, } \\
20 \mathrm{~cm} .\end{array}$ \\
\hline \multirow[b]{3}{*}{15} & 20 & 0.07 & 0.06 & 0.05 \\
\hline & 30 & 0.08 & 0.07 & 0.07 \\
\hline & 40 & 0.14 & 0.12 & 0.11 \\
\hline \multirow[b]{3}{*}{22} & 20 & 0.05 & 0.05 & 0.05 \\
\hline & 30 & 0.07 & 0.06 & 0.05 \\
\hline & 40 & 0.1 & 0.09 & 0.08 \\
\hline \multirow[b]{3}{*}{32} & 20 & 0.05 & 0.04 & 0.04 \\
\hline & 30 & 0.06 & 0.05 & 0.05 \\
\hline & 40 & 0.08 & 0.07 & 0.06 \\
\hline
\end{tabular}

Table 6 : Productivity and operation cost for one hole by using manual digging at auger diameter $25 \mathrm{~cm}$, depth of $40 \mathrm{~cm}$ at moisture content of $15 \%$

\begin{tabular}{||c|c|c||}
\hline \multirow{2}{*}{ Hole depth } & \multicolumn{2}{|c|}{ Auger diameter, $25 \mathrm{~cm}}$. \\
\cline { 2 - 3 } & Hole /day. & Cost, LE./hole \\
\hline 20 & 90 & 0.30 \\
\hline 30 & 60 & 0.50 \\
\hline 40 & 45 & 0.66 \\
\hline
\end{tabular}




\section{CONCLUSIONS.}

The results can be summarized as follows:

The penetration resistance of sandy soil at $15 \%$ moisture content increased by 30 and $40.6 \%$ as compared with of sandy soil at moisture content $22 \%$ and $32 \%$ respectively. The maximum hole productivity rate for sandy soil was 335 hole/h obtained with auger speed of $150 \mathrm{rpm}$, hole depth $20 \mathrm{~cm}$, auger pitch $20 \mathrm{~cm}$ at moisture content $32 \%$. Whereas, the minimum hole productivity of 100 hole/h was obtained with auger speed of $75 \mathrm{rpm}$, hole depth $40 \mathrm{~cm}$ and auger pitch $10 \mathrm{~cm}$ at moisture content $15 \%$. The maximum fuel consumption was $0.59 \mathrm{~L} / \mathrm{h}$ was obtained with auger speed of $150 \mathrm{rpm}$, hole depth $40 \mathrm{~cm}$, and auger pitch $10 \mathrm{~cm}$. The maximum power requirements $1.91 \mathrm{~kW}$ was obtained with auger speed of $150 \mathrm{rpm}$, hole depth $40 \mathrm{~cm}$, auger pitch $10 \mathrm{~cm}$ and moisture content $15 \%$.

- The maximum operation cost was 0.14 L.E./hole at auger pitch $10 \mathrm{~cm}$ and hole depth $40 \mathrm{~cm}$. The operation costs by using a hole digger attached to a power tiller decreased by about $371 \%$ compared with manual digging .

\section{REFERENCES.}

Awady, M. N., 1978, Engineering of tractors and agricultural machinery, Text Bk., col. Ag., Ain-shams U., 5 th Ed. : 164-167. ( In Arabic. ) ( Updating 1998 ).

Chaaban, M. A., El Awady, M. N., Yehia, I., and Khalil, S. K. 2007, Factors affecting the design of a hole digger attached to a power tiller, environmental, J. Environ. Sci., Vol. 15, No. 1: 83 111.

El-Shal, M. S., 1993, A study on some parameters affecting post-hole digger efficiency, Misr J. Agri. Eng., 10 (4): 888 - 899.

Kapnehko, A. H., E-Heb, A. A. and XA-Ahck, B. M., 1976, Farm Machinery (in Russian), Hbl., Book, Moscow: 432-434.

Kathirvel, K., Job, T., Karunanithi, R., Swaminathan, K., 1990, Development of auger digger as attachment to power tiller, AMA, Agr. Mech. In Asia, Africa and Latin America, 21(4): 9-10.

Khalil, S. K., 2008, Development and design of a hole digger to minimize required energy for operation and side effect on agricultural soil, Ph. D., Inst. Environ. Studies and Res., Ain Shams Univ. : 20 - 41. 
Miniaei,S. and Alizadeh, 2000, Design and development of auger drill for attachment to two-wheel tractors, Ag. Sc. And tech., 14(1): 1928.

Purtskhvanidze, M., Keller,N., 1990, Hole digger for slopes, Farm Mechanization (in Russian), No. 3: 38.

Scripnic, V., and Babicin, P., 1968, MASTAGRICOLE, (Book), Romania: 170-191.

Yehia, I., M. H. Kabeel and S. K. Khalil (2009) Affecting factors on performance of a developed hole digger. Misr J. Ag. Eng. 26(2): 1036-1053.

$$
\begin{aligned}
& \text { "الملخص العربى } \\
& \text { دراسة بعض العوامل المؤثرة على أداء حفار جور الأرئ } \\
& \text { فى الأراضى الرملية }
\end{aligned}
$$

د. ميرفت محمد عطاللة (')، د. خليل سيد خليل(') )، د. محمد طه عبيد (')

يهدف هذا البحث إلى دراسة بعض العو امل المؤثرة على أداء حفار جور المطور المعلق على إتى

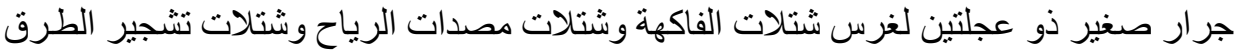

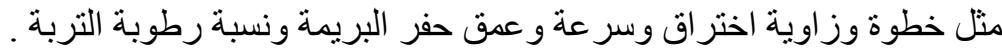

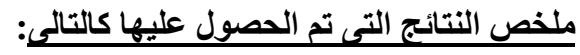

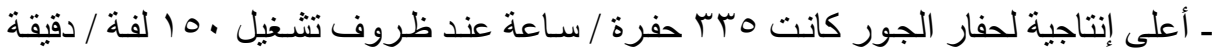

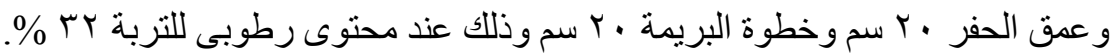

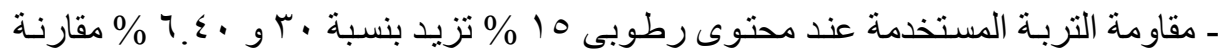

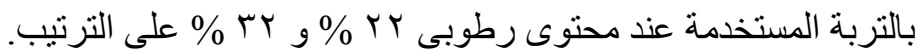

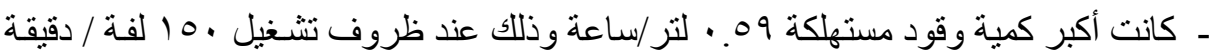

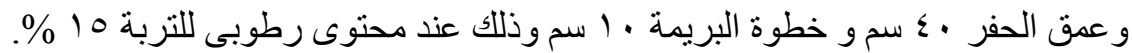

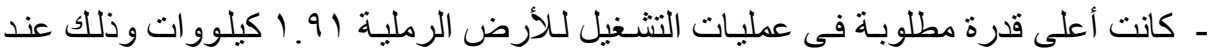

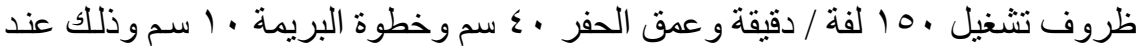

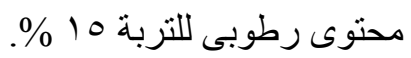

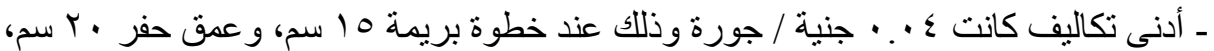

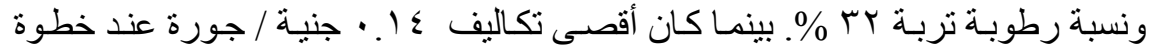

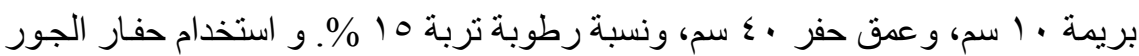

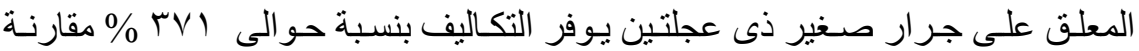
بعمليات الحفر اليدوية.

(1) باحث ، (Y) باحث أول ، معهد بحوث الهندسة الزراعية. 